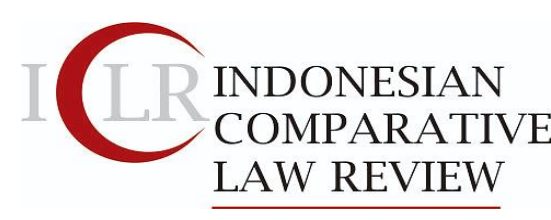

Volume 1 No 2, June 2019

P-ISSN: 2655-2353, E-ISSN: 2655-6545
Article Info:

Received : $02-07-2019$

Revised : :02-08-2019

Accepted : 20-08-2019

http://dx.doi.org/10.18196/iclr.1210

\title{
Unitary, Federalized, or Decentralized?: The Case Study of Daerah Istimewa Yogyakarta as The Special Autonomous Regions in Indonesia
}

\author{
Ming-Hsi Sung ${ }^{1}$, Hary Abdul Hakim ${ }^{2}$ \\ 1, 2 Department of Financial and Economic Law, Asia University, \\ Taiwan \\ E-mail: ${ }^{1}$ minghsi_sung@asia.edu.tw \\ ${ }^{2}$ haryabdulhakim7@gmail.com \\ ${ }^{1}$ Assistant Professor \& Director, East Asia Law Center, Department of \\ Financial and Economic Law, Asia University, Taiwan P \\ ${ }^{2}$ Research Assistant, PAIR Labs; Assistant Research Fellow, East Asia Law Center, \\ Department of Financial and Economic Law, Asia University, Taiwan
}

\begin{abstract}
The professed constitutional unitary state claim has been highly debated. Some argue that Indonesia shall be a unitary state in name, pursuant to Article 1 Para. III of the Indonesian Constitution, but Constitutional reforms after 1998 when the autocratic President Gen. Soeharto stepped down granted broad authority to local government, leading Indonesia to a quasi-federation situation in practice. On the other hand, some stick to the aforementioned Article, insisting that decentralization embedded in the Constitution Article 18 Para. II is by no means making Indonesia federal. This article takes the Act No. 13 of 2012 on Special Region of Yogyakarta (the Daerah Istimewa Yogyakarta)
\end{abstract}

granting autonomy to Daerah Istimewa Yogyakarta as a case study to argue for the latter, asserting that the case merely exemplifies the decentralization characteristic embedded in the Constitution. This paper first examines the political features of federalism through a historical legal perspective, showing that the current state system in Indonesia is decentralized but not federalized. This paper concludes that the recognition of Daerah Istimewa Yogyakarta as an autonomous region is simply a practice of constitutional decentralization. This paper also higlights that with recent political development, echoing that the decentralization theory is not a product of legal interpretation, but a constitutional and political reality.

Keywords: Special Autonomous region; unitary state; Federal system; Decentralization; Yogyakarta; Keistimewaan

\section{Introduction}

The issue of special autonomy region in Indonesia has recently been a hotly debated issue of Indonesian Constitution. Through the Act No. 13 of 2012 (Keistimewaan Daerah Istimewa Yogyakarta, the Daerah Istimewa Yogyakarta 

Special Autonomy Act, KDIY hereinafter)

Daerah Istimewa Yogyakarta (Yogyakarta Special Autonomy Region, DIY hereinafter) has been granted special autonomy, and thereby DIY possesses the special power to conduct her own governmental system, and to stipulate rules specifically for the DIY region. Nevertheless, this autonomous power creates a conflicting situation in Indonesia-despite the fact that Indonesia constitutionally proclaims a unitary state status, she otherwise has a special region with a separate and distinguished autonomous governmental system. Whether or not the situation has brought any impact or change to Indonesia's claimed state status, and what causes Indonesia as a unitary state to adopt a seemly ambivalent special autonomy system, are two issues worthwhile for a social-legal discussion.

Referring to legal historical review, the fact that Indonesia is a unitary state after the 1945 Constitution entered into force on August 18, 1945 is undoubted. The Constitution clearly declared that "the Indonesian State is a unitary State in the form of Republic" (Article 1 para. (1) of the 1945 Constitution). 1 However, this fact became disputed later. On December 27, 1949, Indonesia was forced to change into a federation, the Republic of the United States of Indonesia (RIS hereinafter), which consists of 7 states and 9 autonomous regions, according to the agreement of Konferensi

\footnotetext{
${ }^{1}$ Indonesian 1945 Constitution Article 1 (1) The State of Indonesia shall be a unitary state, with the form of a Republic. (2) Sovereignty is vested in the people and implemented pursuant to the Constitution. (3) The State of Indonesia is a state based on the rule of law. See

http://www.unesco.org/education/edurights/media /docs/b1ba8608010ce0c48966911957392ea8cda405d8.p df (last visited March 1, 2020)
}

Meja Bundar (KMB-Round Table Conference) in 1949 with the Dutch Colonial Authorities and Bijeenkomst voor Federaal Overleg (The Federal Deliberation Assembly, BFO hereinafter). ${ }^{2}$

RIS did not last long. RIS dissolved on August 17, 1950, and Indonesia was rebuilt after combining regions from Sabang to Merauke. Thus, since 1950, Indonesia has officially returned to a unitary state system and replaced the 1949 Federal Constitution of the United States of Indonesia by the Provisional Constitution of 1950 (UUDS 1950 hereinafter) on 17 August 1950. However, The Provisional Constitution (UUDS) is temporary in nature, since Article 134 of the UUDS mandates that "as soon as possible the Constituent Assembly and the Government should establish the Constitution of the Republic of Indonesia which will replace this 1950 Constitution".

Because the UUDS once made Indonesia federal, the appeal for Indonesia to adopt a federal state system has remained after 1949.3 For example, Amien Rais, as a reform figure and co-founder of the Indonesian People's Consultative Assembly, proposes Indonesia to become a federation in order to avoid the breakup of the

\footnotetext{
2 Jakob Tobing, Unitary State of the Republic of Indonesia, Jan 6, 2015, Institute Leimena, available at http:/ / leimena.org/eng/2015/01/06/unitary-state-ofthe-republic-of-indonesia1/?fbclid=IwAR15haIB9z8NUNmARfcCjAd_WrVaG4 97GWGafvDq39ShtjVJnGPijmWeLSs (last visited Jul 27, 2019)

3 Rizang Wrihatnolo, Federal State or Unitary State (Indonesia, Between The Choices of Federal State, Unitary State and Decentralization), avalaible at https://www.bappenas.go.id/files/7013/5228/2209/ rizang_20091015092930_2292_0.rtf (last visited Jan. 30 2020).
} 
Indonesian state. ${ }^{4}$ After all, the federal state system was a cogent alternative to solve the nation's long lasting disintegration and separation problems. ${ }^{5}$

Moreover, in Indonesia, regional autonomy (otonomi daerah, or "Otda") is simply a loose term used by government ministers and the media to describe the delegation of authority and functions from the central to regional governments, as promulgated in Law No 22 of 1999. Law 22 of 1999 on Pemerintahan Daerah (Regional Governance) ${ }^{6}$ and its partner, Law No.25 of 1999 on the Perimbangan Keuangan Antara Pemerintah Pusat dan Daerah (Fiscal Balance between the Central Government and the Regions). ${ }^{7}$ These two laws accommodate the framework for transferring authority, human and financial resources from the central government to the regions, 8

${ }^{4}$ Kompasiana, Kenapa Sistem Negara Federasi Tidak Cocok untuk Indonesia?, available at https://www.kompasiana.com/dendy166/59a47e2e7 dd0952ca43f7202/kenapa-sistem-negara-federasitidak-cocok-untuk-indonesia (last visited Jul 27, 2019)

${ }^{5}$ Ricklefs, M.C. (2008) [1981]. A History of Modern Indonesia Since c.1300 (4th ed.). London: MacMillan. ISBN 978-0-230-54685-1. P. 365-366.

6 This law sets up the framework for regions to regulate and manage their own interests. Therefore, this law is in accordance with Article 2 paragraph 1 of the Constitution, which provides: "The territory of the Unitary State of the Republic of Indonesia is divided into Provincial Regions, District Regencies and Municipal Areas that are autonomous" Law 22 of 1999 available

http://dpr.go.id/dokjdih/document/uu/UU_1999_2 2.pdf (last visited March 1, 2020)

${ }^{7}$ After the implementation of regional autonomy, the regions may get $70 \%$ of the revenue of the management of their own natural resources to be utilized for the advancement of their own regions. Law No.25 of 1999 available at http://dpr.go.id/dokjdih/document/uu/UU_1999_2 5.pdf(last visited March 1, 2020)

${ }^{8}$ What is regional autonomy, August 2000, available at https://www.downtoearth- establishing a new paradigm in the implementation of regional autonomy, since the laws have provided regional autonomy broadly in accordance with democracy, community participation, equity, and consideration, to provinces and various regions. ${ }^{9}$ But using the term autonomy by no means indicates that Indonesia would adopt federalism in a strict sense.

Decentralization has been provided to explain the aforementioned transfer of authority. Although since the Dutch and Japanese colonial period up to the early Independence in 1945, decentralization has a constitutional foundation in Indonesia as mentioned in Article 18 (2) of 1945 Constitution "(2) The regional authorities of the provinces, regencies and municipalities shall administer and manage their own affairs according to the principles of regional autonomy and the duty of providing assistance (Tugas Pembantuan)",10 this paper argues that the recent policies regarding Indonesian decentralization/regional autonomy need to be understood in a broadened historical, political and legal setting. Indonesia by no means consists of states under the state. With the existence of great diversities within and among the regions, Indonesia has to take the territorial decentralization system as a central value in order to give the central authorities to manage regions and provinces in this country. Those regional governments in fact

indonesia.org/story/what-regional-autonomy (last visited Jul 27, 2019)

9 Meiza and Simanjuntak R., 2018, Pengaruh Desentralisasi terhadap Masuknya Investasi pada 32 Provinsi di Indonesia, Simposium Nasional Keuangan Negara (SMKN), p. 1003.

${ }^{10}$ Maribeth Erb, Priyambudi Sulistiyanto and Carole Faucher, 2005, Regionalism in Post-Suharto Indonesia, Routledge Curzon, New York, p. 3. 
act as the representatives of the central government in the provinces/regions. Furthermore, Indonesia as a state with extensive territory, has to rely on regional decision-making to make her government efficient. ${ }^{11}$ Finally, democratization after 1999 also plays an important role in the formation of the decentralization policy. ${ }^{12} \mathrm{At}$ this time Indonesia is carrying out the most rapid and widespread decentralization efforts in response to the request for implementation of decentralization, and this fact was supported and responded by the House of Representatives that enacted two abovementioned laws (Law No. 22 of 1999 on Pemerintahan Daerah and the Law No. 25 of 1999 on the (Perimbangan Keuangan Antara Pemerintah Pusat dan Daerah) at once on April 1999. Thus, the recognition and implementation of special autonomy regions in Indonesia illustrate decentralization in Indonesia, though for certain political reasons, when one looks into the socialpolitical backgrounds of the formation of this policy.

\section{Analysis and Discussion}

\subsection{Historical Review of Constitutional} Situations in Indonesia: To be Unitary or Federal?

Generally speaking, there are two types of states status internationally, i.e. unitary and federal. Adopting the unitary system seems to be inevitable for Indonesia

\footnotetext{
11 Tierney, S., May 2009, Federalism in a Unitary State: A Paradox too Far, Regional \& Federal Studies, Routledge, Vol. 19(2), 237-253, p. 238.

12 Rudy, Desentralisasi Indonesia: Memupuk Demokrasi dan Penciptaan Tata Pemerintah Lokal, Jurnal Ilmu Hukum, Universitas Lampung, ISSN 19785186, Vol 1, Number 1, Januari- April 2007.
}

mainly because of political realities. The Republic of Indonesia has become independent on August 17, 1945, after a long period of the Dutch colonial rule and Japanese wartime occupation. The Independence also proclaimed jurisdiction over regions from Sabang in Sumatra to Merauke in Papua, many of which possess different cultures from the authorities in Jakarta. ${ }^{13}$ Nationalism therefore was the most important core value across the country during that time.

In terms of law, pursuant to the 1945 Constitution, it is understandable that the Indonesian founders prefer the idea of Indonesia as a unitary state in name after the Independence. The idea is clearly written in the 1945 Constitution Article 1 Paragraph $1:$ "The state of Indonesia shall be a unitary state in the form of a republic". ${ }^{14}$ This constitutional design in state status was surely made to help unify a highly diversified Indonesia, which consists of vast archipelago of more than 13,667 islands, around 300 ethnic and sub-ethnic groups, and more than 668 languages and dialects that are native to Indonesia. ${ }^{15} \mathrm{~A}$ unitary state also means that all regions and provinces in Indonesia are controlled by the central government, and all national policies implemented nationwide are made in Jakarta. There is no tolerance for any diversion in any local region. Namely, all

\footnotetext{
${ }^{13}$ Encyclopedia Britannica, Indonesia Government and Society, available at https://www.britannica.com/place/Indonesia/Theat re-and-dance (last visited July 12, 2019).

${ }^{14}$ Article 1 (1) of Indonesian 1945 Constitution.

15 Jacques Bertrand, Oct 2007, Indonesia's QuasiFederalist Approach: Accommodation Amid Strong Integrationist Tendencies, International Journal of Constitutional Law, Volume 5, Issue 4, 576-605; p.581.
} 
regions and provinces are deemed equal and well controlled by the central government.

Nevertheless, there is another article that seems contradictory to the unitary state status claimed by the Article 1 of the Indonesia Constitution. According to Section VI Article 18 (Article 18A and Article 18B), which is the constitutional basis for the implementation of the contradiction in Indonesia, the division of authority between the central government and the local regions/provinces is stipulated in detail, and the central government only retains residual power. 16 These two articles were enacted on the second amendment to the 1945 Constitution on August 18 2000. ${ }^{17}$ In this

16 Wiyono Suko, (2010), Reaktualisasi Pancasila dalam kehidupan Berbangsa dan bernegara, Malang: Wisnuwardhana press, $\mathrm{p}$.20-21

17 Article 18 (1) The Unitary State of the Republic of Indonesia is divided into provinces and a province is divided into kabupaten and kota, with each province, kabupaten and kota having its own regional administration, regulated by law. (2) The administration of a province, of a kabupaten, and of a kota shall regulate and manage its own government matters in accordance with the principles of regional autonomy and the duty of providing assistance. (5) A regional administration shall exercise the broadest possible autonomy, except for matters of governance that are determined by law as the prerogative of the Central Government. (6) A regional administration shall have the right to adopt regional regulations as well as other rules to implement autonomy and the duty of providing assistance. (7) The organization and mechanisms of implementing regional administration are to be regulated by law. Article 18A (1) Relations as to authority between the central government and the administrations of a province, a kabupaten, a kota, as well as between a province and a kabupaten or a kota, are to be regulated by law with special regard for the specificity and diversity of each region. (2) Relations as to finance, public services, the exploitation of natural and other resources between the central government and the regional administrations are to be regulated by law and implemented in a just and synchronized way. Article 18B (1) The State shall recognize and respect entities of regional administration that possess a specificity or a distinctiveness that are to be regulated by law. (2) The State shall recognize and respect, to be amendment, there totally were 25 article changes/additions, and among them there were 8 important adjustments, namely, (1) regional/decentralized autonomy;

Recognition and respect of specific or special units of local government and to the unity of indigenous peoples and their traditional rights; (3) Function affirmations and rights of DPR (Dewan Perwakilan Rakyat, the House of Representatives); (4) The affirmation of the NKRI (Negara Kesatuan Republik Indonesia, National Republic of Indonesia) as an archipelago that characterizes the archipelago with territories whose boundaries and rights are established by law; (5) The expansion of constitutional guarantees of human rights; (6) State defense and security systems; (7) Separation of TNI (Tentara Nasional Indonesia, the Indonesian Military) structure and function with POLRI (Polisi Republik Indonesia, the Indonesia Police); and (8) the setting of the flag, language, emblem of the state, and national anthem. ${ }^{18}$ Delegation of government power and authority to regions from the central governments obviously is the core of this amendment, though the official term employed is decentralization.

Some argue that this constitutional shift makes Indonesia federal or quasifederal. ${ }^{19}$ In fact, Indonesia once was a

regulated by law, the homogeneity of societies with customary law along with their traditional rights for as long as they remain in existence and in agreement with societal development and with the principle of the Unitary State of the Republic of Indonesia.

18 See http:/ / ditjenpp.kemenkumham.go.id/htn-danpuu/685-perubahan-undang-undang-dasar-antaraharapan-dan-kenyataan.html(last visited Feb. 28, 2020) 19 See "Quasi-federalism" in Indonesia, available at https://www.forest-trends.org/wp-

content/uploads/imported/6-quasi-federalism-inindonesia-pdf.pdf (last visited Feb. 28, 2020); Rizang Wrihatnolo, Federal State or Unitary State, available at 
federation. ${ }^{20}$ The federal system shortly adopted by Indonesia in 1949-1950 was imposed by the Dutch for a "divide and rule" strategy. ${ }^{21}$ Lieutenant Governor General of the Dutch, H.J. van Mook first developed the federalized strategy to integrate the Republic of Java by establishing large federal states in Sumatra, Kalimantan and the "Great East".22 The change of the state form of Indonesia into a federation, the Republic of the United States of Indonesia [hereinafter Republik Indonesia Serikat (RIS) ${ }^{23}$ ], was approved by

https://www.bappenas.go.id/files/7013/5228/2209/ rizang_20091015092930_2292_0.rtf (last visited Feb. $28,2020)$

20 According to Wheare (1964), federalism is the method of dividing powers of government in a state so that general and regional governments are each within a sphere, coordinate and independent. See Ikeanyibe Okechukwu., July 2014, Three-Tier Federative Structure and Local Government Autonomy in Brazil and Nigeria, Mediterranean Journal of Social Sciences MCSER Publishing, Vol. 5 No. 15, Rome-Italy. p. 560. Furthermore, Elazar proposed the definition of Federalism as: "Federal principles are concerned with the combination of self-rule and shared rule. In the broadest sense, federalism involves the linkage of individuals, groups and polities in lasting but limited union, in such a way as to provide for the energetic pursuit of common ends while maintaining the respective integrities of all parties. Federal systems do this by constitutionally distributing power among general and constituent governing bodies in a manner designed to protect the existence and authority of all. In federal systems, basic policies are made and implemented through negotiation in some form so that all can share in the system's decision-making and executing processes See Lane, Jan-Erik., 2011, Federal Realities, University of Freiburg, International Journal of Politics and Good Governance, Volume 2, No.2.1 Quarter I. p. 2.

${ }^{21}$ Gabriel Ferrazzi, Using the "F" Word: Federalism in Indonesia's Decentralization Discourse, Publius, Vol. 30, No. 2 (Spring 2000), Oxford University Press, pp. 63-85.

22 Anthony Reid, 2007, Federalism in Asia "Indonesia's Post-Revolutionary Aversion to Federalism", Edward Elgar Publishing Limited, United Kingdom, p. 144.

${ }^{23}$ RIS states consist of seven state parties, namely, (1) Republic of Indonesia State, (2) East Indonesia State, (3) Pasundan State, (4) East Java State, (5) Madura State, (6) East Sumatra State and (7) South Sumatra Sate. While, some region ae included as the autonomy region namely, (1) Central Java, (2) West Kalimantan, (3) the Round Table Conference-the "Konferensi Meja Budar [hereinafter KMB] 24" held in the Hague. Several parties were involved in $K M B$, including Indonesia which was represented by Drs. Moh. Hatta, Mr. Moh. Roem, and Prof. Dr. Mr. Soepomo, the Federal Assembly or Bijeenkomst voor Federal Overleg (BFO), and the Dutch. The United Nations Commission for Indonesia (UNCI) as a representative of the United Nations also joined this agreement. 25

On December 18, 1949, Ir. Soekarno as the president of the RIS announced the new constituents for the first cabinet, a "national business cabinet, with due regard to the desires of the parties," 26 namely, Drs. Hatta, Ide Anak Agung Gde Agung, Sultan Hamengku Buwono IX of Yogyakarta and Sultan Hamid II of West Borneo. On December 20, 1949 sixteen ministers were sworn in as the cabinet:

Dayak Besar, (4) Banjar, (5) Southeast Kalimantan, (6) East Kalimantan, (7) Bangka, (8) Belitung, and (9) Riau. ${ }^{24}$ Konferensi Meja Bundar (KMB) was held from August 23, 1949 to November 2, 1949, and at that time the Indonesian delegation was led by Moh. Hatta. KMB concludes that the Netherlands surrender full sovereignty over Indonesia to RIS unconditionally, and recognizes RIS as an independent and sovereign country.

See https://www.kompasiana.com/azzahraf/5cb66cfecc5 2837f7c131342/konferensi-meja-bundar-kmb-danpengakuan-kedaulatan (last visited March 1, 2020)

${ }^{25}$ Portal Sejarah, Sejarah Republik Indonesia Serikat (1949-1950), Jun 3, 2017, available at http:/ /idsejarah.net/2017/06/sejarah-republikindonesia-serikat-1949.html (last visited Aug 23, 2019)

26 Herbert Feith, The Decline of Constitutional Democracy in Indonesia, Jakarta, Equinox Pub., 2007, p. 48. 
Table of Cabinet

\begin{tabular}{|c|c|c|c|}
\hline Ministry & & & Party \\
\hline $\begin{array}{l}\text { Prime Minister and } \\
\text { Minister of Foreign } \\
\text { Affairs }\end{array}$ & Drs. Moh Hatta & RI & Nonparty \\
\hline Home Affairs & Ide Anak Agung Gde Agung & $\begin{array}{l}\text { East } \\
\text { Indonesia }\end{array}$ & Nonparty \\
\hline Defense & $\begin{array}{l}\text { Hamengku Buwono I, Sultan } \\
\text { of Yogyakarta }\end{array}$ & RI & Nonparty \\
\hline Finance & $\begin{array}{l}\text { Mr. Sjafruddin } \\
\text { Prawiranegara }\end{array}$ & RI & Masjumi \\
\hline Prosperity & Ir. Juanda & RI & Nonparty \\
\hline Education and Culture & Dr. Abu Hanifah & RI & Masjumi \\
\hline Labor & Mr. Wilopo & RI & PNI \\
\hline Justice & Prof. Mr. Dr. Supomo & RI & Nonparty \\
\hline $\begin{array}{l}\text { Communication and } \\
\text { Public Work }\end{array}$ & Ir. Herling Laoh & RI & PNI \\
\hline Information & Arnold Mononutu & $\begin{array}{l}\text { East } \\
\text { Indonesia }\end{array}$ & PNI \\
\hline Health & Dr. Johannes Leimena & RI & Parkindo \\
\hline Social Affairs & Mr. Kosasih Purwanegara & Pasundan & Nonparty \\
\hline Religious Affairs & K.H. Wachid Hasjim & RI & Masjumi \\
\hline State & $\begin{array}{l}\text { Hamid II, Sultan of } \\
\text { Pontianak }\end{array}$ & $\begin{array}{l}\text { West } \\
\text { Kalimanta } \\
\mathrm{n}\end{array}$ & Nonparty \\
\hline State & Mr. Mohammad Roem & RI & Masjumi \\
\hline State & Dr. Suparmo & Madura & Nonparty \\
\hline
\end{tabular}

Resource: https://wawasansejarah.com/sejarah-republik-indonesiaserikat/?fbclid=IwAR2TBybCB5DAXElfjg8vwV04KSgnzXdfEmsfdfi1kf2PqhcdMBXcmO YO1

The federal constitution was Republic of the "United States of Indonesia," promulgated on December 27, 1949. The and Article 1 expressly described the state designation in the constitution was the structure as federal: 


\author{
"An independent and sovereign Republic of the \\ United States of Indonesia is a democratic and \\ constitutional state-law in the form of a \\ federation". 27
}

The Republic of the United States of Indonesia consisted of 16 member states and autonomous regions, and the first and foremost among the states was the Indonesian Republic, according to Article 2 of the 1949 constitution. 28 Most of the other states and all of the autonomous regions had been sponsored by the Dutch in an effort to counteract the influence of the Indonesian Republic. Furthermore, the federal constitution provided another featured system of federalism - a bicameral legislature, consisting of a house of representatives and a senate (the senate was

\footnotetext{
${ }^{27}$ See

http://hukum.unsrat.ac.id/pres/konstitusi_ris.pdf (last visited March 1, 2020)

28 The Republic of the United States of Indonesia covers all regions of Indonesia, namely, the joint regions:

a. The Republic of Indonesia, with regions according to the status quo as mentioned in the Renville Agreement on 17 January 1948; State of East Indonesia; Pasundan State, including the Djakarta Federal District; East Java State; Madura State; The State of East Sumatra, with the understanding, that the status quo Asahan Selatan and Labuhan

Batu related to the State of East Sumatra remains in force; South Sumatra Country;

b. State units which are upright themselves; Central Java; Bangka; Belitung; Riau; West Kalimantan (Special Region); Dajak Besar; Bandjar area; Southeast Kalimantan; and East Kalimantan;

a. and $b$. it is the territories which with independence determine their own destiny to be united in the federation of the Republic of the United States of Indonesia, based on those stipulated in this Constitution and again

c. the rest of Indonesia which is not part-region
}

a body of government appointees from the states and autonomous regions). ${ }^{29}$

However, the federal government system that resulted from the $K M B$ did not last long. The recognition of sovereignty on December 27, 1949 actually led to a call for national unity movement that not only emerged from the Indonesian elite, but also from all civil groups. 30 This movement demanded the federal state design to be transformed into a unitary one, because it is not in accordance with the ideal of the country as stipulated in the 1945 Constitution. In fact, the RIS' dissolution even strengthened the wishes of the member states that expect to return to the unity of Indonesia. Finally, the dissolution of RIS characterized by the formation of the Provisional Constitution Act (UndangUndang Dasar Sementara/UUDS) in 1950. ${ }^{31}$ This Provisional Constitution Act serves as a sign of the re-establishment of Indonesia as a unitary state which came into force on 17 August 1950.32

In the 1945 Constitution amendment process during 1998-2002, an input from a small group of citizens was also discussed in terms of changing Indonesia from a unitary state into a federation. The promotor who support Indonesia become federal state was

\footnotetext{
29 Leyser J, Legal Development in Indonesia, The American Journal of Comparative Law, Vol. 3 No. 3, Summer 1954, 399-411, p. 400.

30 Haryono Rinardi, Dari RIS Menjadi Negara RI: Perubahan Bentuk Negara Indonesia pada tahun 1950, Jurnal Ilmu Humaniora, Vol. 12, No. 2, 181-192, p. 182.

${ }^{31}$ Rifai Shodiq Fathoni, Republik Indonesia Serikat, (1949-1950), Oct 1, 2016, available at http:/ / wawasansejarah.com/sejarah-republikindonesia-serikat/\#_ftn1 (last visited Jul 20, 2019) 32 See http://www.dpr.go.id/dokjdih/document/uu/1657. pdf (last visited March 1, 2020)
} 
driven by a prominent reform figure, Amin Rais, 33 who promotes the idea of Indonesia's future to be transformed from a unitary state into a federal state, together with the Partai Amanat Nasional (National Mandate Party) and several other reform figures, including Adnan Buyung Nasution, Ichlasul Amal, Anhar Gonggong, Faisal Basri, Sri Soemantri, 34 Ismail Sunny, 35 Romo Mangun Wijaya, and dan Dawam Rahardjo. But these ideas didn't gain enough support, and was not accepted by the congress. 36 The reason for this rejection is the concern that if Indonesia turns into a federal state then separatism movement might follow. 37

\footnotetext{
${ }^{33}$ As one of the leading supporters of democracy, his speech at the Salman Mosque of ITB is an important agenda in order to unite the public's perception of the demands for reform. For a more complete description see Amien Rais' speech titled "Succession 1998: A Must". In Amien Rais, Suara, Amien Rais Suara Rakyat, Gema Insani Press, Jakarta, 1998, p. 21

${ }^{34}$ Sri Soemantri argues that justice for regions can be better realized through a federal state design. See interview with Sri Soemantri, Jurnal Pasar Modal Indonesia, Januari 2000, hlm. 45-60.

${ }^{35}$ Ismail Sunny asserts that the idea of a federal state is a path that can bridge a unitary State and separatism. The federation idea should not be interpreted as a divided Indonesia state, because it is considered to be an adhesive of national unity. See Republika, 6 Desember 1999.
}

36 According to BJ. Habibie (Indonesian President year 1998-1999), the constitutional provision of regional autonomy by no means equal to federalism. See Bj. Habibie, Detik-Detik yang Menentukan: Jalan Panjang Indonesia Menuju Demokrasi, THC Mandiri, Jakarta, 2006, p. 266-288.

37 According to Moh. Mahfud MD., the reason why Indonesian people would not support is because the people misunderstand the meaning of a federal state and the fear that a federal state would make Indonesia a potential divided country. See Ni'matul Huda dan Despan Heryansyah, Kompleksitas Otonomi Daerah Dan Gagasan Negara Federal Dalam Negara Kesatuan Republik Indonesia, Jurnal Hukum Ius Quia Iustum Faculty of Law, Universitas Islam Indonesia, Vol 26, issue 2, Mei 2019, pp 238-258, p.242; see also Ni'matul Huda dan Despan Heryansyah, Kompleksitas Otonomi Daerah Dan Gagasan Negara Federal Dalam
The federalist demand was ultimately answered by the aforementioned policy of autonomy. Thus, this policy clearly is the result of a compromise between the demands of the federalists and the unitarists. Meanwhile, this policy can also appease the separatists. The fifth paragraph of the additional Article 37 of the Constitution regulating the procedure for changing the 1945 Constitution thus reiterated and emphasized that "particularly, regarding the form of unitary state of the Republic of Indonesia, there can be no change." 38

Therefore, from a legal historical perspective, the fact that Indonesia in terms of constitution is unitary but not federal is clear, though this fact might maintain the unitary republic system in name only. Federalism only had been instrumentally adopted for uniting this massive country with specific colonial crafty plot, but at last backfired with outweighed demand and support for unity from the people. The latest amendment of the 1945 Constitution even reassures the unitary state form. Indonesia as a federal state thus was a historical past event, has been a political suggestion, but is not a political practice, at least nominally in official stance, in modern Indonesia.

Regardless of the legal historical review and constitutional re-assertion of the $4^{\text {th }}$ amendment in Article 37, the recognition of special autonomous region in 2014 in Indonesia has provoked another challenge to the unitary state form. To test the official proclamation of the unitary state form, it is

Negara Kesatuan Republik Indonesia, Jurnal Hukum Ius Quia Iustum Faculty of Law, Universitas Islam Indonesia, Vol 26, issue 2, Mei 2019, pp 238-258

${ }^{38}$ Indonesian 1945 Constitution Article 37 Paragraph 5 
necessary to examine the issue of special autonomous region.

\subsection{Historical Review of Constitutional Situations in Indonesia: To be Unitary or Federal?}

\subsubsection{Constitutionally Decentralized in De- sign but Instrumentally Employed in Practice}

Decentralization as a constitutional design to delegate a certain degree of meaningful autonomy to subnational tiers of government has been popular in the world, especially for most developing countries that had been inflicted by authoritarianism and colonialism. One of the reasons for this system's popularity lies on attempts to maintain national unity through linking both central and regional governments. ${ }^{39}$ Among the South East Asian post-colonial and postauthoritarian countries, Indonesia is a good example of implementing decentralization. 40

The constitutional design of decentralization in the 1945 Constitution nevertheless seemingly contradicts the consistent official unitary claim. The practice of regional autonomy in fact has been adopted earlier since the revolution era after the Indonesian independency in 1945,

\footnotetext{
${ }^{39}$ Ronald, Wittek and Woltjer, Decentralization and Governance in Indonesia, Springer, Volume 2, 2006, Springer Int. Pub., London, p. 5.

${ }^{40}$ Decentralization means a process of transferring power, resources and responsibilities from the central to the sub-national levels of government, creating a horizontal relationship among a multitude of actors both public and private. Decentralization also aims to promote good governance by enabling citizen participation and democratic elections. In other words, the outcome of decentralization should result in a more participatory government for citizens and improved delivery of public services because of the local participation and accountability. See http://www1.worldbank.org/publicsector/decentralizat ion/political.htm\#2 (last visited March 1, 2020)
}

although some argue that the practice in Indonesia has been largely one of "deconcentration," 41 not decentralization. 42 UU No. 1 Tahun 1945 tentang Kedudukan Komite Nasional Indonesia (The Law No. 1 of 1945 on the Stipulations of the Position of Regional National Committee) $)^{43}$ emphasizes on the aspirations of people's sovereignty through the formation of representative bodies in each region and province. The law

${ }^{41}$ See. World Bank Group, “Deconcentration --which is often considered to be the weakest form of decentralization and is used most frequently in unitary states-- redistributes decision making authority and financial and management responsibilities among different levels of the central government. It can merely shift responsibilities from central government officials in the capital city to those working in regions, provinces or districts, or it can create strong field administration or local administrative capacity under the supervision of central government ministries," available http:/ / www1.worldbank.org/publicsector/decentrali zation/admin.htm\#top. (last visited March 1, 2020)

42 Alm, James, Robert H. Aten and Roy Bahl, 2001, "Can Indonesia Decentralise Successfully? Plans, Problems and Prospects", Bulletin of Indonesian Economic Studies, Vol. 37, No. 1, 2001: 83-102.

${ }^{43}$ For the first law of the regional government is about the day-to-day administration with the assistant of the Regional National Committee: e.g Law No. 1 of 1945, see

http://www.dpr.go.id/dokjdih/document/uu/813.p df (last visited March 1, 2020). There in fact are a series of legislations for advancing regional autonomy: e.g. Law No. 22 of 1948 (focusing on the arrangement of democratic regional government structures), see http://ditjenpp.kemenkumham.go.id/arsip/ln/1948/ uu22-1948.pdf (last visited March 1, 2020); generally, Indonesia has two types of autonomous regions, namely, ordinary autonomous regions and special autonomous regions stipulated by the Law No. 1 of 1957,

see http://www.dpr.go.id/dokjdih/document/uu/1160. pdf (last visited March 1, 2020); Law No. 18 of 1965, see http://www.dpr.go.id/jdih/index/id/1474 (last visited March 1, 2020); moreover, Indonesia is generally divided into two types of Autonomous Region, one for the implementation of the principle of decentralization and the other termed Administrative Region: e.g. Law No. 5 1974, see http://www.dpr.go.id/jdih/index/id/746 (last visited March 1, 2020) 
provides three types of regional autonomy, namely, residency (keresidenan), regency, and city. ${ }^{44}$ On the other hand, the autonomy is set as a principle of local governance clearly mentioned in Article 18 of 1945 Constitution. 45

After the authoritarian President Gen. Soeharto who had been in power for 32 years from 1966 to 1998 felled down in 1998, 46 the implementation of regional autonomy system was increasingly apparent and have been seriously carried out by the government. 47 The 1945 Constitution was amended and new laws were passed to democratize Indonesia. As part of this democratization, several steps have been taken by the central government to increase the flexibility of the political system, out of pressure in favor of decentralization and devolution of power, and accommodation of easing demands from ethnonationalist/separatist groups in East Timor, Aceh, and Papua.

Decentralization has been seriously carried out by the central government for the first time by the enactment of those new laws. The enactment of Law No. 22 of 1999 on Pemerintahan Daerah (Regional Governance) 48 and the Law No. 25 of 1999 on the Perimbangan Keuangan Antara Pemerintah

${ }^{44}$ Sani Safitri, Sejarah Perkembangan Otonomi Daerah di Indonesia, Jurnal Criksetra, Vol. 5, Number 9, Februari 2016, 79- 83, p. 80.

45 See the Article 18 of 1945 Constitution.

46 Anwar Nasution, Government Decentralization Program in Indonesia, Asian Development Bank Institute, 2016, available at https://www.adb.org/sites/default/files/publication /201116/adbi-wp601.pdf (last visited July 10, 2019)

${ }^{47}$ Ahmad, Ehtisham and Ali Mansoor, 2002, Indonesia:

Managing Decentralization, IMF Working Papers No. $\mathrm{WP} / 02 / 136$

${ }^{48}$ Available at

http://www.dpr.go.id/jdih/index/id/423 (last

visited March 1, 2020)
Pusat dan Daerah (Fiscal Balance Between the Central Government and the Regions) ${ }^{49}$ employed as the guide to implement decentralization evidenced the seriousness, and at the same time, theoretically proved the fact that the practice of decentralization in the previous regime before 1999 tends to be deconcentration only.

Under the new system, which came into force on early January 2001, municipal and district governments accept greater authority, especially in terms of political, administrative and economic affairs within their own jurisdiction. Provincial administrations with appointed governors from the central government in Jakarta which previously had been responsible for coordinating Jakarta policy directives during Suharto's New Order gained no new power, and have been devolved most of their authority to the second-tier provincial level. On the other hand, Aceh 50, Papua, Yogyakarta and Jakarta, which are governed

\section{${ }^{49}$ Available at}

http://www.dpr.go.id/dokjdih/document/uu/UU_1 999_25.pdf (last visited March 1, 2020)

${ }^{50}$ Law No. 11of 2006 regarding Ache's autonomy is stated differently. Article 1 paragraph 2 states that:

"Aceh is a provincial region which is a special legal community unit given special authority to regulate and manage its own government affairs and the interests of local communities in accordance with the laws and regulations in the system and principles of the Unitary State of the Republic of Indonesia based on the Constitution of the Republic of Indonesia. 1945, led by a Governor. "Aceh's privileges reflect more in the field of religious life in the form of the implementation of Islamic sharia for adherents in Aceh, while maintaining harmony between religious believers, including: worship, Ahwal Alsyakhshiyah (family law), Muamalah (civil law), Jinayah (criminal law), Qadha '(justice), Tarbiyah (education), Da'wah, Syiar, and the defense of Islam. Available at http://mohammaddarry-fisip12.web.unair.ac.id/artikel_detail-79332-

Politik\%20Pemerintahan\%20Lokal-

Aceh\%20Jogja\%20Papua.html. (last visited March 1, 2020) 
by separate arrangements of special autonomy, 51 have won more authority than before.

The role of regional autonomy was then approved by establishing two enactments in 2004 (Law No. 32 of 2004 on the implementation of autonomy 52 and Law No. 33 of 2004 on the financial balance ${ }^{53}$ ), so that each region could have the power for progressing natural resources. ${ }^{54}$ According to Law No. 32 of 2004 on Pemerintah Daerah (Regional Governance) Article 1 paragraph 5 , the definition of regional autonomy is the right, authority, and obligation of autonomous regions to regulate and manage their own government affairs and the interests of local communities in accordance with statutory regulations. Furthermore, Law No. 33 of 2004 amends the previous Law on the Perimbangan Keuangan Antara Pemerintah Pusat dan Daerah (Fiscal Balance Between the Central Government and the Regions) and therefore local regions can have more financial power. With this new law, the district/city government is positioned as a subordinate of the provincial government, even in the case of making local regulations (Peraturan Daerah) on regional budget and expenditure (Anggaran Pendapatan dan Belanja Daerah, APBD), as

\footnotetext{
${ }^{51}$ Miller, M.A., Decentralizing Indonesian City Spaces as New "Centers", International Journal of Urban and Regional Research, 37 (3), May 2013, 834-848, p. 838.

52 Available at

http://www.dpr.go.id/jdih/index/id/33 (last visited March 1, 2020)

53 Available at http://www.dpr.go.id/jdih/index/id/34 (last visited March 1, 2020)

54 S. Endang Prasetyowati, Meneropong Konsepsi Negara Kesatuan Dengan Sistem Otonomi Seluasluasnya, Jurnal Keadilan Prograsif, Vol. 2, Number 2, Sep 2011, 137-146, p. 139.
}

mentioned in article 69 of Law No. 33 of 2004.55

But meanwhile this law also reminds the existence of the connection the state and the local autonomous regions. Law No. 32 of 2004 confirms that the local government in organizing government affairs has a connection with the central government and with the other local governments. The connection includes the connection of authority, finance, general service, utilization of natural resources, and other resources. 56

The state further invalidated Law No. 32 of 2004 in 2014 by enacting Law No. 23 of 2014 that provides and emphasizes the new idea of co-administration (tugas pembantuan). 57 According to Law No. 23 of 2014, the authority of regional government includes the following matters.

1. The regional government shall administer governmental affairs according to the principle of autonomy and coadministration to the greatest extent in accordance with the system of the Unitary State of the Republic of Indonesia.

\footnotetext{
55 Article 69 “(1) In the framework of implementing Regional Government, the Regional Government prepares RKPD which refers to the Government Work Plan as a single unit in the national development planning system. (2) RKPD as referred to in paragraph (1) is the basis APBD draft preparation".

56 The meaning of "administrative relations" is the relationship that occurs as a consequence of the policy of organizing the local government which is a unity in organizing the State administration system. The meaning of "regional relationship" is the relationship that occurs as a consequence formed and the establishment of autonomous regions held in the territory of the unitary Republic of Indonesia. Thus, the area of the region is one unit of the state intact and rounded

${ }^{57}$ Available at http://www.dpr.go.id/jdih/index/id/1605 (last visited March 1, 2020)
} 
2. Based on the principle of $\mathrm{CO}^{-}$ administration, the regional government carries out concurrent government affairs surrendered by the central government as the basis for the implementation of regional autonomy.

3. The regional government's authority in carrying out general government affairs comes from the authority of the president, and the implementation of those affairs is delegated to the governor and regent / mayor, and shall be financed by the State Budget (Anggaran Pendapatan dan Belanja Negrara/APBN). 58

On March 18, 2015, Law No. 9 of 201559 amends Law No. 23 of 2014, additionally narrowing down the scope of power and authority that local governments and autonomous regions may have. According to Article 9 of the 2015 Law, government affairs consist of absolute governmental affairs (Pemerintahan Absolut), concurrent governmental affairs (Pemerintahan konkuren), and general governmental affairs (Pemerintahan umum). The absolute governmental affairs are entirely under the authority of the central government. The general governmental affairs are under the authority of the president as the head of the State. Only the concurrent governmental affairs are under the authority shared and divided between the central government and local governments/autonomous regions. 60 The

\footnotetext{
${ }^{58}$ Available at https://soppengkab.go.id/penjelasanuu-nomor-23-tahun-2014-tentang-pemerintahandaerah/

${ }^{59}$ Available at https://soppengkab.go.id/penjelasanuu-nomor-23-tahun-2014-tentang-pemerintahandaerah/

60 Nurdiyana, Pengawasan Terhadap Implementasi Peraturan Daerah Dihubungkan Dengan Uu No.9 Tahun 2015 Tentang Perubahan Kedua Atas UU No.
}

extent of the authority the local regions can have are surely reduced again.

To sum up, the pace of implementing decentralization in Indonesia has been indecisive, if not reluctant. According to the 1945 Constitution, the territory of Indonesia is divided into provinces. Article 18 (1) of the Constitution provides: "The Unitary State of the Republic of Indonesia shall be divided into provinces [...], each of which shall have regional authorities which shall be regulated by law." 61 Provincial governments have the power to regulate the matters under their jurisdictions. 62 Based on the aforementioned Article 18 of the Constitution and the legal enactments, decentralization therefore is pro forma embedded in the Indonesian Constitution, and has been carrying out after 1999 along with the trend of democratization and the need to appease separatism through decentralization enactments. Nevertheless, the step toward decentralization has retreated since 2014 when the central government started to assert coadministration and confine the scope of authority delegated to local regions. Decentralization in Indonesia thus is obviously mere an instrument employed by the central government that has controlled the extent of decentralization.

23 Tahun 2014 Tentang Pemerintahan Daerah Dalam Menciptakan Tata Kelola Pemerintahan Yang Baik (Good Governance), Jurnal Surya Kencana Dua: Dinamika Masalah Hukum dan Keadilan Vol. 4 No.1 Juli 2017, 1-18, p.10.

${ }^{61}$ Article 18 (1) of Indonesia 1945 Constitution

62 Lily Bauw, Special Autonomy of Papua: A Review from the Perspective of the Unitary State of the Republic of Indonesia, Papua Law Journal, Volume 1 Issue 1, 1-26, Nov 2016, p. 2. 


\subsubsection{The Case of Yogyakarta Special Au- tonomy Region}

In terms of special autonomy region, Article 18 B (1) of the 1945 Constitution reconfirms decentralization, providing that the State recognizes and respects units of regional authorities that are special and distinct, which shall be regulated by law. 63 The Constitution expressly extends her decentralism to special autonomy regions. The case of recognizing Daerah Istimewa Yogyakarta (Yogyakarta Special Autonomous Region, DIY) a special autonomy region is conspicuous.

$D I Y$ is a special region that has special authority in conducting her governance system in the unitary state of Republic Indonesia based on her distinctive history. Before the Indonesian independence, DIY was a region that had her own government, Daerah Swapraja, which means territories that have the right to self-governance. This term was used as an equivalent to the term in the Dutch colonial period, zelfbestuur (plural zelfbesturen), namely, Kasultanan Ngayogyakarta Hadiningrat (Ngayogyakarta Hadiningrat Sultanate) and Kadipaten Pakualaman (Duchy of Pakualaman). ${ }^{64}$ Kasultanan Ngayogyakarta Hadiningrat was founded by Pangeran Mangkubumi or Sultan Hamengku Buwono I in 1755, and Kadipaten Pakualaman was founded by Pangeran Notokusumo or Adipati Paku Alam I in 1813.

Daerah Istimewa Yogyakarta has been privileged to enjoy autonomy that is

\footnotetext{
${ }^{63}$ Article 18 B (1) of Indonesia 1945 Constitution ${ }^{64}$ Yogykarta BPKP, Sejarah Keistimewaan Yogyakarta, available http://www.bpkp.go.id/diy/konten/815/sejarahkeistimewaan-yogyakarta (last visited Jun 7, 2019).
}

guaranteed by the law for a historicalpolitical reason. 65 The Yogyakarta special autonomy region was established through a merger agreement on August 191945 between Yogyakarta Sultanate and Paku Alaman Kingdom on one hand, and the Indonesia government on the other. ${ }^{6}$ Sri Sultan Hamengku Buwono IX and Sri Pakualaman stated that Daerah Kesultanan Yogyakarta and Daerah Pakualaman would join the then newly independent state and became part of Indonesia, with the condition to be entitled as Daerah Istimewa Yogyakarta (DIY). Sri Sultan Hamengku Buwono IX and Sri Paku Alam VIII became the Head and the Vice Head of Daerah Istimewa Yogyakarta. The fact is stated on three documents:

1. The Charter Made by Sri Sultan Hamengku Buwono IX and Sri Paku Alam VIII, in 19th August 1945 and President RI.

2. The Mandate of Sri Sultan Hamengku Buwono IX and Sri Paku Alam VIII, in 5th September 1945. (In separated documents)

3. The Mandate of Sri Sultan Hamengkubuwono IX and Sri Paku Alam VIII, in 30th October 1945. (In one document) ${ }^{67}$

Moreover, leaders' intention to maintain the cultural distinctiveness of

\footnotetext{
65 Bayu Dardias Kurniadi, Yogyakarta in Decentralized Indonesia: Integrating Traditional Institution in Democratic Transitions, Jurnal Sosial dan Ilmu Politik 190-203, Vol 13, Number 2, November 2009.

66 Achmad Ubaidillaah, A Study of Good Governance Index in Yogyakarta Special Region between 2012 and 2016, Jurnal Kebijakan dan Administrasi Publik, 13-28, Vol. 21 (1), May 2017.

${ }^{67}$ Yogyakarta BPK, Kajian Hukum Tentang Keistimewaan Daerah Istimewa Yogyakarta, (2013), available at http://yogyakarta.bpk.go.id/wpcontent/uploads/2013/06/Keistimewaan-DIY.pdf, (last visited Jun 5, 2019).
} 
Yogyakarta is crucial for the recognition. Both Sri Sultan Hamengku Buwono $X$ of Kasultanan Ngayogyakarta Hadiningrat, the governor of DIY, and Sri Paduka Paku Alam IX of Kadipaten Pakualaman, the deputy governor of DIY, have tried hard to preserve the cultural values, traditions, and social unification of Java, where Yogyakarta locates. In order to fulfill the preservation task, the government of DIY therefore demands maintaining cultural distinctiveness and claims the power to maintain it.

The Indonesia central government enacted Law No. 3 of 1950 concerning the Establishment of the Special Region of Yogyakarta 68 that authorized DIY to handle various affairs in running the government as well as special matters, in response to the DIY leaders' demand to maintain the cultural uniqueness of DIY. Article 1 (2) Law No. 3 of 1950 expressly indicates that Yogyakarta is unique, stressing that it is not a province, but a province-level special region. This difference mainly reflects in the election of leaders. Regional leaders adopt the hereditary system instead of democratic election. 69

\footnotetext{
${ }^{68}$ Available at:

https://www.hukumonline.com/pusatdata/detail/lt 519f2fb32ad5b/node/950/uu-republik-indonesia-no3-tahun-1950-pembentukan-daerah-istimewajogjakarta\# (last visited March 2, 2020)

${ }^{69}$ The DIY Privileges Arrangement in the statutory regulations since the establishment of the Unitary Republic of Indonesia remains consistent by recognizing the existence of a special region. Law 3/1950 on the Establishment of the Special Region of Yogyakarta is very short (only 7 articles and an appendix to the list of autonomy authorities). Source: Dinas Kebudayaan DIY available at https://budaya.jogjaprov.go.id/artikel/detail/209penjelasan-uu-keistimewaan-diy. (last visited March 1, 2020) Article 1(1) stated that: Regions which include the area of the Sultanate of Yogyakarta and the Paku
}

The autonomy power of DIY was furtherly advanced through the enactment of Law No. 13 of 2012 on Keistimewaan Daerah Istimewa Yogyakarta,70 which were ratified on 31 August 2012 and promulgated on 3 September 2012.71 Article 4 indicates that this law aims to enable DIY to realize good and democratic governance, peace and wellbeing of the people, to guarantee the Unity in Diversity (ke-bhineka-tunggal-ika-an), and to institutionalize the roles and responsibilities of the Kasultanan and Kadipaten in maintaining and developing the culture of Yogyakarta which is the nation's cultural heritage. The authority as special autonomy was stipulated in Article 7 paragraph 2, which includes: procedures for filling government positions, duties and authorities of the governor and deputy governor 72 , DIY local government

Alaman area shall be designated as Regions Special Jogjakarta (2) The Special Region of Jogjakarta is at the level of a Province.

70 Available at: http://dpr.go.id/jdih/index/id/273 (last visited March 2, 2020)

71 Pemerintah Daerah DIY, Sejarah, available at https://jogjaprov.go.id/profil/3-sejarah (last visited Jun 25, 2019).

72 The issue the issue about retreating the autonomous status of DIY might be related to the appointment of head regional government here is governor of yogyakarta. The appointment of Sri Sultan Hamengku Buwono as Governor and Sri Paku Alam as Deputy Governor of the Province of DIY does not conflict with the principles of democracy according to the 1945 Constitution because, the determination is a form of privilege of the Province of DIY granted by the state based on the historical background of the kingdom in Yogyakarta. Considering that prior to the independence of the Republic of Indonesia, DIY was a kingdom or sovereign state that had existed and then decided to integrate with the Republic of Indonesia, the Republic of Indonesia could not simply remove the powers that had historically been held by the two sovereign states, especially with regard to regional leadership. The argument strengthens by the compilers of the 1945 Constitution and strengthened by modifiers of the 1945 Constitution, the 1945 Constitution was prepared by containing provisions 
institutions, culture, land, and spatial planning.

Nevertheless, the fact that DIY as an autonomous region by no means indicates that DIY is a federal state. The central government, though has authorized DIY to handle various governmental matters, maintains the unitary state assertion. As implied in Article 5 of Law No. 13 of 2012, that the special autonomy region status and the authority along with this status delegated to Yogyakarta is to carry out the will of the Indonesian 1945 Constitution "to create the democratic governance," 73 and therefore, the recognition of special autonomy status of DIY is nothing but implementation of decentralization embedded in the Constitution of the unitary republic of Indonesia. On the other hand, Law No. 23 of 2014 and Law No. 9 of 2015 that have reduced the autonomy power of local regions apply to the DIY case either. As a result, although DIY once was claimed to be unique, she still has to yield to the central government's instrumental use of decentralism.

\section{Conclusion}

Based on the discussion above, this paper would like to argue that in terms of

which give recognition and respect to DIY related to the right of origin. Source: Fajar, Helmi et. Al, Status Keistimewaan Daerah Istimewa Yogyakarta dalam Bingkai Demokrasi Berdasarkan Undang-Undang Dasar 1945 (Studi Kasus Pengisian Jabatan Kepala Daerah dan Wakil Kepala Daerah), Jurnal Konstitusi, Vol. 8, No. 6, Desember 2011.

${ }^{73}$ Fajar, Helmi et. Al, Status Keistimewaan Daerah Istimewa Yogyakarta dalam Bingkai Demokrasi Berdasarkan Undang-Undang Dasar 1945 (Studi Kasus Pengisian Jabatan Kepala Daerah dan Wakil Kepala Daerah), Jurnal Konstitusi, Vol. 8, No. 6, Desember 2011. p.1072. legal historical review, Indonesia is a unitary state. All regions in Indonesia are controlled by the central government. Meanwhile, it is unarguable that Indonesia once was a federal state. But because of anti-colonialism pervaded in Indonesia, federalism is somewhat a taboo nowadays. Although there are contradicting legal provisions and government designs as well as practices of decentralization such as DIY, the official stance regarding Indonesia as a unitary state have been consistently claimed and reiterated in legal documents by the government. Regardless of scholarly challenges that assert Indonesia is federal or quasi-federal, the official stance maintaining Indonesia is unitary, at least in name, is quite steady. Although decentralization embedded in the 1945 Constitution seems somewhat federal, or contradictory to the official unitary claim, the implementation of this policy in practice counter-proves the political reality that Indonesia remain unitary, and the policy has been employed instrumentally, after the central government enacted new laws on 2014 and 2015 to make decentralization retreated. The special autonomy region system in the meantime has to succumb to the central government's instrumental use of decentralization. In short, Indonesia is unitary and decentralized according to the 1945 Constitution, but the decentralization is merely instrumentally employed as a condition in dealing with political pressure, such as democratization and separatism.

Of course, democratization that has begun since the 1999 reform period will make the distribution of power and authority to local regions and provinces in Indonesia become inevitable. One may 
expect that when new chapter of reformation in Indonesia has begun, in order to compromise with democratization, or even some other political problems, decentralization still will be used as an instrument in Indonesia in the future

\section{References}

\section{Books}

Ahmad, Ehtisham and Ali Mansoor, 2002, Indonesia: Managing Decentralization, IMF Working Papers No. WP/02/136;

Anthony Reid, 2007, Federalism in Asia "Indonesia's Post-Revolutionary Aversion to Federalism", Edward Elgar Publishing Limited, United Kingdom;

Herbert Feith, The Decline of Constitutional Democracy in Indonesia, Jakarta, Equinox Pub., 2007;

Johnny Ibrahim, 2006, Teori dan Metode Penelitian Hukum Normatif, Malang: Bayu Media;

Maribeth Erb, Priyambudi Sulistiyanto and Carole Faucher, 2005, Regionalism in Post-Suharto Indonesia, Routledge Curzon, New York;

Meiza and Simanjuntak R., 2018, Pengaruh Desentralisasi terhadap Masuknya Investasi pada 32 Provinsi di Indonesia, Simposium Nasional Keuangan Negara (SMKN;

Mukti Fajar ND, Yulianto Achmad, 2009, Dualisme Penelitian Hukum, Yogyakarta: Pensil Komunika;

Tri Widodo W. Utomo, Aug 2009, Balancing Decentralization and Deconcentration: Emerging Need for Asymmetric Decentralization in the Unitary State, Discussion Paper No. 174, Nagoya University, Japan;

Utomo, Tri Widodo, 2011, Building Good Governance through Decentralization in Indonesia (Recognizing some Inhibiting Factors in the Implementation Stage);

Wiyono Suko, (2010), Reaktualisasi Pancasila dalam kehidupan Berbangsa dan bernegara, Malang: Wisnuwardhana press.

\section{Journal}

Achmad Ubaidillaah, A Study of Good Governance Index in Yogyakarta Special Region between 2012 and 2016, Jurnal Kebijakan dan Administrasi Publik, 13-28, Vol. 21 (1), May 2017;

Bayu Dardias Kurniadi, Yogyakarta in Decentralized Indonesia: Integrating Traditional Institution in Democratic Transitions, Jurnal Sosial dan Ilmu Politik 190-203, Vol 13, Number 2, November 2009;

Fajar, Helmi et. Al, Status Keistimewaan Daerah Istimewa Yogyakarta dalam Bingkai Demokrasi Berdasarkan Undang-Undang Dasar 1945 (Studi Kasus Pengisian Jabatan Kepala Daerah dan Wakil Kepala Daerah), Jurnal Konstitusi, Vol. 8, No. 6, Desember 2011;

Gabriel Ferrazzi, Using the " $F$ " Word: Federalism in Indonesia's Decentralization Discourse, Publius, Vol. 30, No. 2 (Spring 2000), Oxford University Press;

Haryono Rinardi, Dari RIS Menjadi Negara RI: Perubahan Bentuk Negara Indonesia pada tahun 1950, Jurnal Ilmu Humaniora, Vol. 12, No. 2, 181-192;

Ikeanyibe Okechukwu., July 2014, Three-Tier Federative Structure and Local Government Autonomy in Brazil and Nigeria, Mediterranean Journal of Social Sciences MCSER Publishing, Vol. 5 No. 15, Rome-Italy;

Jacques Bertrand, Oct 2007, Indonesia's QuasiFederalist Approach: Accomodation Amid Strong Integrationist Tendencies, International Journal of Constitutional Law, Volume 5, Issue 4, 576-605;

James, Robert H. Aten and Roy Bahl, 2001, "Can Indonesia Decentralise Successfully? Plans, Problems and Prospects", Bulletin of Indonesian Economic Studies, Vol. 37, No. 1, 83-102;

Lane, Jan-Erik., 2011, Federal Realities, University of Freiburg, International Journal of Politics and Good Governance, Volume 2, No.2.1 Quarter I;

Leyser J, 1954, Legal Development in Indonesia, The American Journal of Comparative Law, Vol. 3 No. 3, Summer, 399-411;

Lily Bauw, Special Autonomy of Papua: A Review from the Perspective of the Unitary State of the 
Republic of Indonesia, Papua Law Journal, Volume 1 Issue 1, 1-26, Nov 2016;

Miller, M.A., Decentralizing Indonesian City Spaces as New "Centers", International Journal of Urban and Regional Research, 37 (3), May 2013, 834-848;

Ni'matul Huda dan Despan Heryansyah, Kompleksitas Otonomi Daerah Dan Gagasan Negara Federal Dalam Negara Kesatuan Republik Indonesia, Jurnal Hukum Ius Quia Iustum Faculty of Law, Universitas Islam Indonesia, Vol 26, issue 2, Mei 2019;

Nurdiyana, Pengawasan Terhadap Implementasi Peraturan Daerah Dihubungkan Dengan Uu No.9 Tahun 2015 Tentang Perubahan Kedua Atas UU No. 23 Tahun 2014 Tentang Pemerintahan Daerah Dalam Menciptakan Tata Kelola Pemerintahan Yang Baik (Good Governance), Jurnal Surya Kencana Dua: Dinamika Masalah Hukum dan Keadilan Vol. 4 No.1 Juli 2017;

Ronald, Wittek and Woltjer, Decentralization and Governance in Indonesia, Springer, Volume 2, 2006, Springer Int. Pub., London;

Rudy, Desentralisasi Indonesia: Memupuk Demokrasi dan Penciptaan Tata Pemerintah Lokal, Jurnal Ilmu Hukum, Universitas Lampung, ISSN 1978-5186, Vol 1, Number 1, Januari- April 2007.

S. Endang Prasetyowati, Meneropong Konsepsi Negara Kesatuan Dengan Sistem Otonomi Seluas-luasnya, Jurnal Keadilan Prograsif, Vol. 2, Number 2, Sep 2011, 137-146;

Sani Safitri, Feb 2016, Sejarah Perkembangan Otonomi Daerah di Indonesia, Jurnal Criksetra, Vol. 5, Number 9, 79- 83;

Suadi Zainal, Transformasi Konflik Aceh dan Relasi Sosial-Politik di Era Desentralisasi, Jurnal Sosiologi, Vol. 21, No. 1, Jan 2016;

Tierney, S., May 2009, Federalism in a Unitary State: $A$ Paradox too Far, Regional \& Federal Studies, Routledge, Vol. 19(2), 237-253;

\section{Internet}

Anwar Nasution, Government Decentralization Program in Indonesia, Asian Development Bank Institute, 2016, available at https://www.adb.org/sites/default/files/publ ication/201116/adbi-wp601.pdf, last visited July 10, 2019, 6.36 pm;

Encyclopedia Britannica, Indonesia Government and Society, available at https://www.britannica.com/place/Indonesia /Theatre-and-dance, last visited July 12, 2019, 5.35 pm;

Jakob Tobing, Unitary State of the Republic of Indonesia, Jan 6, 2015, Institute Leimena, available at http://leimena.org/eng/2015/01/06/unitarystate-of-the-republic-of-indonesia1/?fbclid=IwAR15haIB9z8NUNmARfcCjAd_W rVaG497GWGafvDq39ShtjVJnGPijmWeLSs, last visited Jul 27, 2019, $9.30 \mathrm{am;}$

Kompasiana, Kenapa Sistem Negara Federasi Tidak Cocok untuk Indonesia?, available at https://www.kompasiana.com/dendy166/59a 47e2e7dd0952ca43f7202/kenapa-sistem-negarafederasi-tidak-cocok-untuk-indonesia.

Pemerintah Daerah DIY, Sejarah, available at https://jogjaprov.go.id/profil/3-sejarah, last visited Jun 25, 2019, 10 pm;

Portal Sejarah, Sejarah Republik Indonesia Serikat (19491950), Jun 3, 2017, available at http:/ /idsejarah.net/2017/06/sejarahrepublik-indonesia-serikat-1949.html, last visited Aug 23, 2019, 4.50 pm;

Ricklefs, M.C. (2008) [1981]. A History of Modern Indonesia Since c.1300 (4th ed.). London: MacMillan. ISBN 978-0-230-54685-1. P. 365-366. last visited Jul 27, 2019, $9.30 \mathrm{am;}$

Rifai Shodiq Fathoni, Republik Indonesia Serikat, (19491950), Oct 1, 2016, available at http://wawasansejarah.com/sejarah-republikindonesia-serikat/\#_ftn1, last visited Jul 20, 2019, 12pm;

Rizang Wrihatnolo, Federal State or Unitary State (Indonesia, Between The Choices of Federal State, Unitary State and Decentralization), Avalaible at https://www.bappenas.go.id/files/7013/5228 L2209/rizang_20091015092930_2292_0.rtf, last visited Jan 2020;

Yogyakarta BPK, Kajian Hukum Tentang Keistimewaan Daerah Istimewa Yogyakarta, (2013), available at http://yogyakarta.bpk.go.id/wp- 
content/uploads/2013/06/Keistimewaan-

DIY.pdf, last visited Jun 5, 2019, 5 pm;

Yogykarta BPKP, Sejarah Keistimewaan Yogyakarta, available

http://www.bpkp.go.id/diy/konten/815/seja

rah-keistimewaan-yogyakarta, last visited Jun 7, 2019, $2.42 \mathrm{am}$.

\section{Regulation}

Indonesian 1945 Constitution

Law No. 23 of 2014 on Local Government (Pemerintah Daerah)

Law No. 13 of 2012 on Keistimewaan Daerah Istimewa Yogyakarta

Law No. 32 of 2004 Local Government (Pemerintah Daerah)

Law 33 of 2004 on Fiscal Decentralization

Law No. 22 of 1999 on Regional Administration

Law No. 25 of 1999 on Revenue Sharing of Central and Regional Government

Law No. 1 of 1945 on Kedudukan Komite Nasional Indonesia

Law No. 3 of 1950 on Establishment of the Special Region of Yogyakarta 